\title{
Aplikasi Data Mining Dengan Metode CHAID Dalam Menentukan Status Kredit
}

\author{
Muhammad Rizki', Muhammad Isnaini Hadiyul Umam², Muhammad Luthfi Hamzah ${ }^{3}$ \\ ${ }^{1,2}$ Program Studi Teknik Industri, Fakultas Sains dan Teknologi, UIN Sultan Syarif Kasim Riau \\ Jl. HR. Soebrantas No. 155 Simpang Baru, Panam, Pekanbaru, 28293 \\ Email: muhammad.rizki@uin-suska.ac.id, muhammad.isnaini@uin-suska.ac.id \\ ${ }^{3}$ Sistem Informasi, Fakultas Sains dan Teknologi, UIN Sultan Syarif Kasim Riau \\ Jl. HR. Soebrantas No. 155 Simpang Baru, Panam, Pekanbaru, 28293 \\ Email : muhammad.luthfi@uin-suska.ac.id
}

\begin{abstract}
ABSTRAK
Seiring dengan digalakkannya Industrial 4.0, data mining menjadi topik yang hangat untuk bahas dikalangan peneliti. Perkembangan teknologi yang begitu cepat memaksa kita untuk dapat mengambil keputusan dengan cepat pula. Kredit macet menjadi salah satu resiko terbesar lembaga keuangan. Resiko kredit macet ini wajib diminimalisir dengan menganalisa faktor status nasabah berdasarkan data personalnya, sehingga dapat dilakukan klasifikasi berdasarkan hubungan antar faktor tersebut. Salah satu kunci utama memenangkan persaingan pasar yaitu dengan menentukan target pasar. Data mining menyediakan banyak alat bantu untuk klasifikasi, salah satunya dengan menggunakan metode analisis CHAID (Chi-square Automatic Interaction Detection Analysis). Diagram pohon keputusan yang dihasilan dari Analisis CHAID dapat memberikan informasi tentang derajat hubungan antara variable independent dan dependent, serta informasi tentang karakteristik masing-masing kategori. Dalam hal ini, analisis CHAID digunakan untuk menentukan klasifikasi nasabah berdasarkan status kredit nasabah sebagai variable terikat dan data pribadi nasabah sebagai variable bebas. Dengan menggunakan uji Chi-square, dari total 7 variables independent, hanya 5 variable yang signifikan dengan variable dependent. Variable-variable tersebut adalah variable independent usia, pekerjaan, pendidikan, jangka waktu dan jumlah pinjaman. Berdasarkan hasil analisis CHAID didapatkan empat kelas. Kelas nasabah dengan pekerjaan sebagai (Aparatur Sipil Negara) ASN merupakan kelas yang memiliki resiko kredit macet yang paling minimal.
\end{abstract}

Kata Kunci: Data mining, Kredit, CHAID, Klasifikasi

\section{ABSTRACT}

Industrial 4.0, data mining has become a hot topic to discuss. The rapid development of technology forces us to make decisions quickly too. Bad Debt is one of the biggest risks in the banking area. The risk of bad debt must be minimized by analyzing status customer based on personal data so we can classify based on the correlation between these factors. One of the strategy to overcome in market is determining market kelompoktation. Data mining provides many tools for classification, one of which is using the CHAID (Chisquare Automatic Interaction Detection Analysis) method. The decision tree diagram generated from the CHAID analysis can provide information about the degree of relationship between the independentt variable and the dependentt variable and information on the characteristics of each class. In this study, CHAID analysis is used to determine customer classification based on the customer's credit status as the dependentt variable and customer personal data as the independentt variable. By using the Chi-square test, out of a total of 7 independentt variables, only 5 variables are significant with the dependentt variable. These variables are the independentt variables of age, occupation, education, period and loan amount. Based on the results of the CHAID analysis, four classes were obtained. The class of customers who work as ASN is the class that has the least risk of bad credit.

Keywords: Data Mining, Credit, CHAID, Classification

\section{Pendahuluan}

Selama ini dalam menjalankan kegiatan perkreditan banyak kredit yang belum dikembalikan sesuai jadwal yang telah ditentukan. Adanya kredit macet tersebut telah menimbulkan kerugian bagi lembaga keuangan terkait. Dalam hal pembiayaan, tingkat pembiayaan yang lebih tinggi disertai dengan risiko kredit macet yang sangat besar. Risiko kredit ini harus diminimalisir agar lembaga keuangan dapat menjaga kelangsungan usahanya agar dapat 
menyediakan produk pembiayaan kepada nasabah sasaran

Menghadapi kenyataan tersebut di atas, maka perlu dilakukan prediksi terhadap status kredit macet lembaga keuangan. Perkiraan status kredit merupakan upaya yang dilakukan oleh lembaga perkreditan untuk menghindari kredit macet atau tunggakan pinjaman yang jatuh tempo. Oleh karena itu, prediksi status kredit macet sangat berguna untuk mengurangi risiko kredit macet dan menempatkan kelompok nasabah yang tepat untuk meminimalkan risiko kredit macet.

Beberapa penelitian terdahulu yang terkait dengan prediksi status kredit yaitu Yohanes dan Siti [1], mempelajari pembentukkan kelompoktasi dengan aplikasi analisis CHAID dengan permasalahan penentuan kelompoktasi nasabah potensial, dimana kelompoktasi nasabah potensial akan meminimumkan resiko kredit macet. Kemudian Lehmann dan Eherler [2], mempelajari profil responder dengan membandingkan CHAID dan analisis dependentsi dalam proses pengambilan keputusan. Yohanes dan Inggried [3], mengetahui kelompoktasi user berdasarkan kepusaan dengan Analisis Chaid. Kemudian Hoare [4], menggunakan metode CHAID untuk membuat klasifikasi dalam dataset. Algoritma CHAID telah terbukti menjadi pendekatan yang efektif untuk memperoleh segmentasi yang cepat tetapi bermakna di mana segmen didefinisikan dalam istilah demografis atau variabel lain yang memprediksi tunggal variabel kriteria kategori (dependen) [5][8].

Untuk meminimalkan risiko kredit dengan memfokuskan pada faktor status nasabah berdasarkan status kredit, kelompoktasi pasar akan didasarkan pada hubungan antara faktor-faktor tersebut (variable terikat) dan variable prediktor (variable terikat). Dengan demikian, metode dependentsi dapat dijalankan dalam proses menghasilkan kelompok berdasarkan variable independent yang memiliki pengaruh besar terhadap variable independent. Namun, sebagai teknik eksplorasi, atau sebagai teknik pilihan terakhir ketika metode tradisional gagal, pohon klasifikasi, menurut pendapat banyak peneliti, tak tertandingi [6][7].

Penelitian sebelumnya yang dilakukan adalah mengidentifikasi kelompok nasabah potensial, dengan harapan dapat meminimalkan risiko kredit macet dengan menggunakan CHAID. Dalam penelitian ini variable bebas yang digunakan sebagai unsur penyusun adalah jenis kelamin, usia, tingkat pendidikan, pekerjaan, sektor kredit dan masa kredit[9][10].

Dalam penelitian ini, analisis CHAID akan digunakan untuk menentukan kelompoktasi pelanggan. Kelompoktasi ini bertujuan untuk mengidentifikasi kelompok nasabah potensial dengan harapan dapat meminimalkan risiko kredit macet.

\section{Metode Penelitian}

Data yang diperlukan untuk penelitian (data nasabah pengguna pembiayaan pemohon kredit. Data ini kemudian dijadikan variable dalam analisis CHAID[11]. Variable dalam penelitian ini meliputi variable dependent dan variable independent yaitu: 1. Variable Dependent

a. Nasabah dengan status pinjaman macet (M).

b. Nasabah dengan status pinjaman tidak macet (TM).

2. Variable Independentt

a. Jenis Kelamin (Laki-laki dan Perempuan)

b. Usia ( $<23$ tahun, 24- 30 tahun, $31-40$ tahun, $41-50$ tahun, $>51$ tahun )

c. Pekerjaan (ASN, Pegawai Swasta, Wiraswasta, Pedagang, Petani)

d. Tingkat pendidikan (SD, SMP, SMA, Diploma, S1/S2/S3)

e. Sektor Kredit (konsumtif, jasa perdagangan pertanian, industi

f. Tenor pembiayaan (5 hingga 100 bulan)

g. Total kredit (<Rp. 500.00, Rp. 500.000 hingga RP. 1.000 .000 , Rp. 1.000.001 hingga Rp. 2.000.000, >Rp. 2000.000)

Preprocessing data meliputi pemilihan data, pembersihan data dan konversi data. Melalui penggabungan, pemisahan, dan penghilangan langkah, analisis chi-square digunakan untuk menentukan prediktor yang signifikan dari variable dependent. Hasil klasifikasi di pohon CHAID akan ditampilkan dalam diagram pohon. Penentuan target pasar didasarkan pada hasil kalsifikasi karakteristik pelanggan saat menganalisis bagan CHAID yang terbentuk[12]

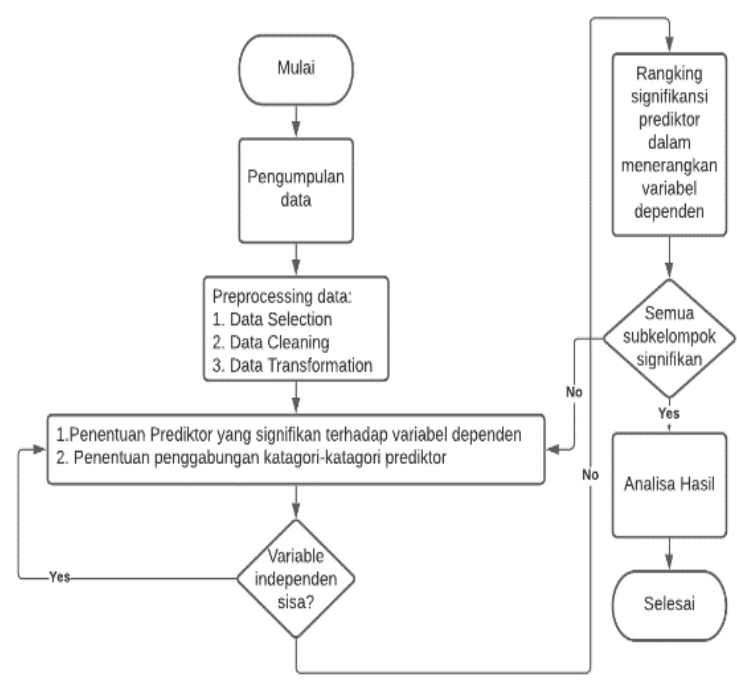

Gambar 1. Diagram alir penelitian 


\section{Hasil dan Pembahasan}

Dengan adanya uji Chi-square dimaksudkan untuk mengetahui hubungan antara status pinjaman kredit yang terbentuk dengan karakteristik dari nasabahnya. Penentuan dan penyusunan deskriptor tiap kelas dilakukan dengan menggunakan metode tabulasi silang menggunakan CROSSTAB SPSS[13].

\begin{tabular}{|c|c|c|c|}
\hline \multicolumn{4}{|c|}{ Chi-Square Tests } \\
\hline & Value & $\mathrm{df}$ & $\begin{array}{l}\text { Asy mp. Sig. } \\
\text { (2-sided) }\end{array}$ \\
\hline Pearson Chi-Square & $45.240^{a}$ & 4 & .000 \\
\hline Likelihood Ratio & 35.026 & 4 & .000 \\
\hline $\begin{array}{l}\text { Linear-by-Linear } \\
\text { Association }\end{array}$ & 29.645 & 1 & .000 \\
\hline Nof Valid Cases & 2421 & & \\
\hline
\end{tabular}

a. 1 cells $(10.0 \%)$ have expected count less than 5 . The minimum expected count is .54

Gambar 2. Hasil Chi-square test untuk usia

Dari gambar 2. diketahui bahwa Chi-square hitung (hasil output SPSS) adalah sebesar 45,240 sedangkan Chi-square tabel (hasil tabel Chi-square) sebesar 9,488. Karena Chi-square hitung lebih besar dari Chi-square tabel $(45,361 \geq 9,488)$, maka $H_{0}$ ditolak berarti terdapat hubungan yang signifikan antara status dengan usia. Kesimpulan yang sama terdapat pada variable-variable pekerjaan dan tingkat Pendidikan.

Namun kesimpulan yang berbeda terdapat pada variable jenis kelamin dimana Chi-square hitung lebih kecil dari Chi-square tabel yaitu 0,007 $\leq 3,841$, maka $\mathrm{H}_{0}$ diterima berarti tidak terdapat hubungan yang signifikan antara status dengan jenis kelamin nasabah. Demikian pula variable sektor kredit dimana Chi-square hitung (hasil output SPSS) adalah sebesar 3,700 sedangkan Chi-square tabel (hasil tabel Chi-square) sebesar 9,488, maka $\mathrm{H}_{0}$ diterima berarti tidak terdapat hubungan yang signifikan antara status dengan sektor kredit.

Variable jangka waktu diketahui bahwa Chi-square hitung (hasil output SPSS) adalah sebesar 28, 316 sedangkan Chi-square tabel (hasil tabel Chi-square) sebesar 19,675. Karena Chisquare hitung lebih besar dari Chi-square table, maka $\mathrm{H}_{0}$ ditolak berarti terdapat hubungan yang signifikan antara status dengan jangka waktu. Pada variable jumlah pinjaman diketahui bahwa Chisquare hitung (hasil output SPSS) adalah sebesar 7,977 sedangkan Chi-square tabel (hasil tabel Chisquare) sebesar 7,815. Karena Chi-square hitung lebih besar dari Chi-square tabel $(7,977>7,815)$, maka ditolak berarti terdapat hubungan yang signifikan antara status dengan jumlah pinjaman. Maka dalam analisis diagram pohon CHAID variable-variable yang tidak signifikan tidak diikut sertakan.

\section{Analisis CHAID}

Tahap awal dalam analisis CHAID adalah tahap pengabungan[14]. Dalam kasus ini variable pekerjaan dibagi menjadi 5 kategori:
1. ASN
2. Pegawai Swasta
3. Wiraswasta
4. Pedagang
5. Petani

Setelah tahap analisis CHAID, variablevariable tersebut kemudian dikelompokkan menjadi 3 kategori, yaitu :

1. Kategori Wiraswasta

2. Kategori Pegawai Swasta

3.Kategori gabungan dari kategori petani, wiraswasta dan kategori pedagang

Hal ini berarti bahwa variable pekerjaan kategori petani, wiraswasta, dan pedagang memenuhi syarat kesignificanan chi-square untuk bisa digabung menjadi satu kategori tunggal berdasarkan analisis CHAID yang ada.

Penggabungan kategori juga terjadi pada variable lainnya, yaitu Jumlah Pinjaman. Dalam penelitian ini variable jumlah pinjaman dibagi menjadi 4 kategori yaitu :

1. < Rp. 500.000, -

2. Rp. 500.000, - hingga Rp. 1.000.000,-

3. Rp. 1.000.001,- hingga Rp. 2.000.000,

4. Rp. 2.000.000,-

Dimana variable ini oleh dikelompokkan menjadi 2 kategori yaitu: 1. < Rp. 2.000.000,-

2. > Rp. 2.000.000,

Hal ini berarti bahwa variable jumlah Pinjaman kategori 1, 2, dan 3 memenuhi syarat untuk bisa digabung menjadi satu kategori berdasarkan analisis CHAID yang ada.

Dari hasil penentuan skala variable dependent dan variable independentt dapat kita ketahui bahwa pada penelitian ini sebenarnya terdapat 5 independent. Dari hasil Chi-square dan diagram pohon CHAID menunjukkan bahwa ada 2 variable independent yang signifikan terhadap variable dependent, yaitu variable pekerjaan, dan jumlah pinjaman. Hal ini juga dapat dilihat dari hasil diagram pohon CHAID, bahwa pohon klasifikasi tersebut mempunyai 2 kedalaman, di mana variable pekerjaan membagi status kredit pada kedalaman ke1, kemudian variable jumlah pendidikan pada kedalaman ke-2. Sehingga ada tiga variable independent lainnya yang tidak mempunyai hubungan significant dengan variable dependent, yaitu variable usia, variable pendidikan, variable jenis kelamin, variable sektor kredit, dan variable masa kredit.

\section{Tahap Pemisahan}

Pada diagram klasifikasi CHAID, variablevariable independent yang berperan dalam pemisahan adalah pekerjaan pada kedalaman pertama, dan jumlah pinjaman pada kedalam kedua. Hasil klasifikasi CHAID memperlihatkan variable independent pertama yang terpilih dalam memisahkan nasabah berdasarkan status nasabah adalah pekerjaan. Pekerjaan merupakan variable independent yang mempunyai nilai $p$-value terkecil 
dengan nilai 0.000 dan nilai chi-square terbesar yaitu 340.681. Kemudian pekerjaan membagi status nasabah dengan menggunakan kategori-kategori yang telah digabung secara optimal menjadi sub kelompok yang baru[15].

Pada sub kelompok yang baru tersebut, dilakukan tahap penggabungan ulang berdasarkan variable independent yang belum terpilih dengan proses yang sama seperti yang dijelaskan pada sub bahasan sebelumnya. Kemudian variable jumlah pinjaman merupakan variable independent selanjutnya yang terpilih dalam memisahkan nasabah berdasarkan status nasabah menjadi sub kelompok baru lagi.

Kesignifikanan variable pekerjaan dan variable jumlah pinjaman dalam membagi status nasabah dapat ditunjukkan pada nilai $p$-value dan chi-square. Apabila nilai $p$-value dari kedua variable independent tersebut kurang dari nilai signifikansi ( $\alpha) 0.05$ yang berarti terdapat hubungan antara kedua variable independent tersebut dengan status nasabah.

Berdasarkan pemisahan tersebut, sebanyak 1084 nasabah mempunyai pekerjaan kategori 1 (ASN), sebanyak 138 nasabah mempunyai pekerjaan kategori 2 (pegawai swasta), dan sebanyak 1199 nasabah mempunyai pekerjaan kategori 3 (Petani, wiraswasta, Pedagang). Nasabah yang mempunyai pekerjaan kategori 1 yaitu nasabah dengan pinjaman yang berstatus tidak lancar (MACET) berjumlah 4 nasabah $(0.4 \%)$, sedangkan 1080 nasabah $(99.6 \%)$ merupakan nasabah dengan pinjaman yang berstatus lancar (TIDAK MACET). Selanjutnya nasabah yang mempunyai pekerjaan kategori 1 dibagi menjadi 2 kelompok berdasarkan penggabungan optimal variable jumlah pinjaman yaitu nasabah dengan jumlah pinjaman kurang dari Rp. 2.000.000 berjumlah 808 nasabah $(0 \%$ nasabah dengan kredit mavet dan $100 \%$ nasabah dengan kredit tidak macet) dan jumlah pinjaman lebih dari Rp. 2.000.000 (1.4\% untuk nasabah dengan pinjaman yang berstatus macet dan $98.6 \%$ untuk nasabah dengan pinjaman yang berstatus tidak macet).

\section{Tahap Pemberhentian}

Pemberhentian dilakukan ketika semua sub kelompok telah dianalisis dan juga telah berisi pengamatan-pengamatan dengan jumlah yang sedikit. Dan pada analisis CHAID, pertumbuhan pohon terhenti dengan dua kedalaman yang merupakan kedalaman maksimum untuk pertumbuhan pohon pada SPSS[16].

\section{Kelompok Nasabah}

Kelompok pada nasabah pembiayaan di lembaga keuangan yang dihasilkan dengan metode CHAID telah diterangkan pada diagram pohon klasifikasi CHAID. Berdasarkan diagram tersebut nasabah dibagi menjadi 4 kelompok dengan karakteristik seperti yang nampak pada tabel 1 .
Tabel 1. Tabel jumlah nasabah dengan pinjaman yang berstatus lancar dan tidak lancar Jumlah Status Jumlah Status

Kelompok

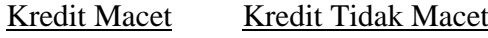

\begin{tabular}{ccc}
\hline 1 & 0 & 808 \\
\hline 2 & 4 & 272 \\
\hline 3 & 50 & 88 \\
\hline 4 & 64 & 1135 \\
\hline Total & 118 & 2303
\end{tabular}

\section{Target Pasar}

Dari empat kelompok yang terbentuk, dapat dihitung jumlah masing-masing nasabah dengan pinjaman yang berstatus macet dan tidak mact dalam tabel 2. Dari tabel tersebut diketahui bahwa kelompok yang memenuhi untuk dijadikan acuan dalam sasaran nasabah adalah pada kelompok 1 . Hal ini berdasarkan acuan bahwa untuk menentukan nasabah baru yang dapat memperkecil kredit macet, maka akan dipilih kelompok-kelompok dengan jumlah nasabah dengan status kredit macetnya terkecil.

Nasabah pada kelompok 1 mempunyai karakteristik sebagai nasabah dengan pekerjaan ASN dan jumlah pinjaman kurang dari Rp. 2.000.000 lebih bisa dipercaya untuk dijadikan sebagai nasabah karena mereka mempunyai penghasilan tetap perbulannya. Disisi lain, jumlah pinjaman kurang dari Rp. 2.000.000 lebih dapat dilunasi tepat waktu daripada jumlah pinjaman yang lebih dari Rp.2.000.000.

Jadi untuk selanjutnya, lembaga keuangan dapat memberikan prioritas pada calon nasabah dengan karakteristik sesuai pada kelompok 1 supaya jumlah pembiayaan dengan status pinjaman tidak lancar dapat diminimalisir.

Dari data perusahaan diketahui jumlah nasabah dengan status kredit tidak macet terbanyak adalah nasabah dengan pekerjaan ASN. Kelompok terbaik sebagai prioritas strategi pasar adalah kelompok 1, yaitu nasabah dengan pekerjaan ASN dan jumlah pinjaman kurang dari Rp. 2.000.000. Hal ini memperlihatkan bahwa keadaan yang terjadi di dalam perusahaan telah sesuai dengan análisis yang dihasilkan

\section{Kesimpulan}

Berdasarkan hasil pengolahan data dan analisis yang telah dilakukan, maka dapat ditarik beberapa kesimpulan sebagai berikut:

1. Pada kasus ini, analisis CHAID mendapatkan empat kelompoktasi yang berbeda, yaitu: 
a. Karakteristik nasabah yang memiliki pekerjaan sebagai ASN dengan jumlah pinjaman $\leq$ Rp. 2.000.000.

b. Karakteristik nasabah yang memiliki pekerjaan sebagai ASN dengan jumlah pinjaman $>$ Rp. 2.000.000 .

c. Karakteristik nasabah dengan pekerjaan sebagai Pegawai Swasta.

d. Karakteristik nasabah dengan pekerjaan sebagai Petani, Wiraswasta, dan Pedagang.

2. Untuk meminimumkan jumlah pinjaman dengan status kredit macet di masa yang akan datang maka Lembaga keuangan sebaiknya memprioritaskan calon nasabah dengan karakteristik nasabah yang memiliki pekerjaan sebagai ASN yang lebih pasti pendapatannya tiap bulan, karena dalam database lembaga keuangan sebagian besar anggota mempunyai pekerjaan sebagai ASN. Hal ini terlihat dari hasil analisis CHAID, kelompok ke-1 (node ke1 pada diagram pohon CHAID) memiliki resiko kredit macet paling rendah sebesar 0,4\% (4/1084) dan besar kelompok 44,8\% (1084/2421) dari total nasabah.

\section{Daftar Pustaka}

[1] Siti Nur, S. (2006). Metode CHAID Untuk Klasifikasi Data Mining (Studi Kasus: Bursa Efek Kuala Lumpur)

[2] Eherler, D., \& Lehmann, T. (2001, September). Responder profiling with CHAID and dependency analysis. In Data Mining for Marketing Applications Workshop, University of Freiburg, Germany. Retrieved on August (Vol. 30, p. 2012).

[3] Hasana, S. N., \& Kunto, Y. S. (2006). Analisis Chaid Sebagai Alat Bantu Statistika Untuk Segmentasi Pasar (Studi Kasus pada Koperasi Syari ah Al-Hidayah). Jurnal Manajemen Pemasaran, 1(2).

[4] Hoare, R. (2004, July). Using CHAID for classification problems. In New Zealand Statistical Association Conference, Wellington, New Zealand.

[5] Magidson J. \& Vermunt JK. (2006). An Extention of CHAID Treebased Segmentation Algoritma to Multiple Dependent variables. Departement of methodology and Statistic, Tilburg University, Netherland.
[6] Hoare R. (2004). Using CHAID for Classification Problems. Wellington: Paper presented at New Zealand Statistical Association 2004 Conference.

[7] Santosa, B. (2007). Data mining teknik pemanfaatan data untuk keperluan bisnis. Yogyakarta: Graha Ilmu, 978(979), 756.

[8] Gorunescu, F. (2011). Data Mining: Concepts, models and techniques (Vol. 12). Springer Science \& Business Media.

[9] Wirania, Y., Mara, M. N., \& Kusnandar, D. (2013). Pembentukan pohon klasifikasi dengan metode CHAID. BIMASTER, 2(1).

[10] Muhajir, M. (2016). Metode Improved CHAID (chi-squared automatic interaction detection) Pada Analisis Kredit Macet BMT (Baitul Mal wa Tamwil). EKSAKTA: Journal of Sciences and Data Analysis, 16(1), 55-63.

[11] Pratiwi, Y. D. (2016). Klasifikasi Alumni FMIPA UNS Menggunakan Metode ChiSquaredautomatic Interaction Detection (CHAID) dan Exhaustivechaid.

[12] Atieh, M. A., Pang, J. K., Lian, K., Wong, S., Tawse-Smith, A., Ma, S., \& Duncan, W. J. (2019). Predicting peri-implant disease: Chisquare automatic interaction detection (CHAID) decision tree analysis of risk indicators. Journal of periodontology, 90(8), 834-846.

[13] Pebrianti, W. (2020). Demografi Pengguna Produk Digital Asli Kota Pontianak Metode Crosstabs. Cakrawala Management Business Journal, 3(1), 571-582.

[14] Kurnia, L. (2017). Analisis Daya Tahan Mahasiswa dalam Melanjutkan Studi dengan Chi-Squared Automatatic Interaction Detection. Sainstek: Jurnal Sains dan Teknologi, 8(1), 56-63.

[15] Atti, A., Ginting, K. B., \& Ndii, M. Z. (2019). Analisis Karakter Dosen Dalam Melakukan Penelitian Dengan Metode Chi-Square Automatic Interaction Detection (Chaid). Jurnal Diferensial, 1(1), 1-6.

[16] Suhendra, M. A., Ispriyanti, D., \& Sudarno, S. (2020). Ketepatan Klasifikasi Pemberian Kartu Keluarga Sejahtera Di Kota Semarang Menggunakan Metode Regresi Logistik Biner Dan Metode Chaid. Jurnal Gaussian, 9(1), 6474. 